This item was submitted to Loughborough's Research Repository by the author.

Items in Figshare are protected by copyright, with all rights reserved, unless otherwise indicated.

\title{
Liquid racism and the Danish Prophet Muhammad cartoons
}

PLEASE CITE THE PUBLISHED VERSION

http://dx.doi.org/10.1177/0011392110372728

PUBLISHER

Sage - on behalf of International Sociological Association (ISA) (@ Simon Weaver)

VERSION

AM (Accepted Manuscript)

LICENCE

CC BY-NC-ND 4.0

REPOSITORY RECORD

Weaver, Simon. 2019. "Liquid Racism and the Danish Prophet Muhammad Cartoons". figshare. https://hdl.handle.net/2134/6680. 
This item was submitted to Loughborough's Institutional Repository (https://dspace.lboro.ac.uk/) by the author and is made available under the following Creative Commons Licence conditions.

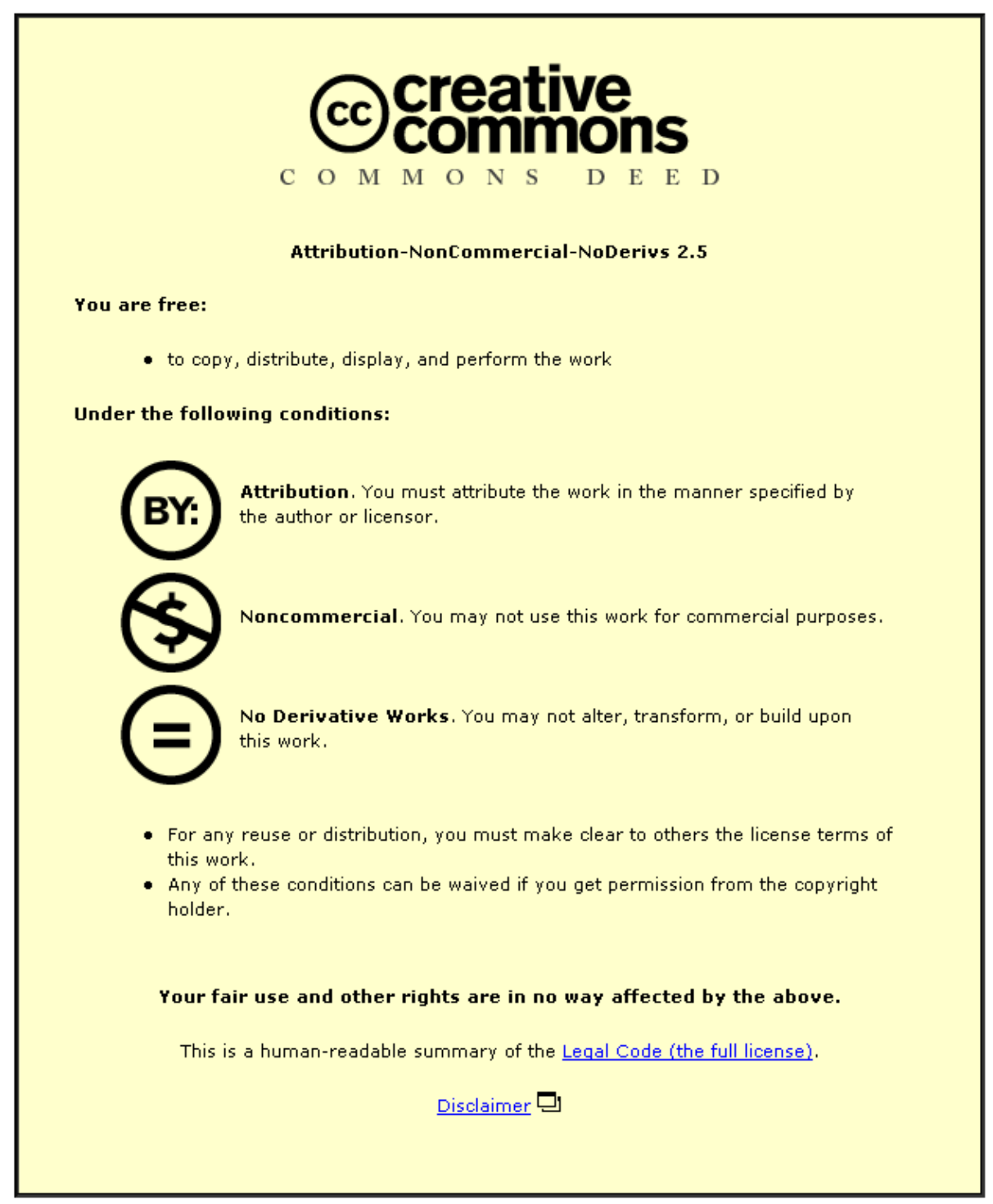

For the full text of this licence, please go to: http://creativecommons.org/licenses/by-nc-nd/2.5/ 


\title{
Liquid Racism and the Danish Prophet Muhammad Cartoons
}

\author{
Simon Weaver
}

\section{Loughborough University}

abstract: This article examines reactions to the October 2005 publication of the Prophet Muhammad cartoons in the Danish newspaper Jyllands-Posten. It does so by using the concept of 'liquid racism'. While the controversy arose because it is considered blasphemous by many Muslims to create images of the Prophet Muhammad, the article argues that the meaning of the cartoons is multidimensional, that their analysis is significantly more complex than most commentators acknowledge, and that this complexity can best be addressed via the concept of liquid racism. The article examines the liquidity of the cartoons in relation to four readings. These see the cartoons as: (1) a criticism of Islamic fundamentalism; (2) blasphemous images; (3) Islamophobic and racist; and (4) satire and a defence of freedom of speech. Finally, the relationship between postmodernity and the rise of fundamentalism is discussed because the cartoons, reactions to them, and Islamic fundamentalism, all contain an important postmodern dimension.

keywords: fundamentalism * Islamophobia * liquid racism * postmodernity * Prophet Muhammad cartoons

Twelve cartoons depicting the Islamic Prophet Muhammad were originally published in the conservative Danish newspaper Jyllands-Posten on 30 September 2005. The events that followed have been widely documented. This article examines what has not been unpacked, the specific detail of the incongruous and rhetorical structure of the cartoons and the effect this had on the debates and reactions that followed. I argue that the incongruity of the cartoons encourages tension and debate in a linguistic frame that does not allow for a clear outcome or 'winner'.

It is necessary to add an early caveat - some contextual definition of the terms 'cartoon' and 'satire' - as both are used in a strictly descriptive rather than normative sense. The term 'cartoon' is employed while not assuming that the Prophet Muhammad cartoons are humorous to all, or anyone. Rather, I use 'cartoon' to describe the images because they were broadly created with the use of structural incongruity, drawn by an artist, and appeared as political artwork in a newspaper that regularly publishes such drawings. Of course, many cartoons that appear in daily newspapers are not funny to all, are offensive to their subject and rely heavily on ridicule as a trope. Furthermore, and as is discussed later, my use of 'satire' is descriptive. It signifies a broad category of political humour and lampooning, rather than a 'noble art' that highlights wrongdoing or shows 'truth to power'. Although not usually acknowledged in such debates, satire is entwined with partisan outlooks and is often an ambiguous art form.

The events that followed the publication of the cartoons included a series of protests from Danish Muslims, subsequent reprinting of the cartoons in over 50 countries and the escalation of protest, with violent protest occurring in some Muslim countries (Butler, 2006). The cartoons were published with an article by the JyllandsPosten culture editor Flemming Rose, which discussed freedom of speech and self- 
censorship, and explained how the Danish writer Kåre Bluitgen had difficulty finding an illustrator to draw Muhammad for a children's book. The article also reported 'that a local comedian said he didn't dare make fun of the Koran' (Whittam Smith, 2006). The controversy was escalated by a delegation of Danish imams touring the Middle East to lobby governments. This impacted on Denmark with the closure of a number of Arab embassies and a consumer boycott of Danish products in the Middle East.

Reaction also included government-organized rioting in some Muslim countries, which resulted in a number of deaths (Butler, 2006). The Organization of the Islamic Conference and Arab League requested that the UN enact sanctions against Denmark and introduce blasphemy laws. The Danish lobbyists had presented a dossier in the Middle East titled 'Dossier about Championing the Prophet Muhammad Peace be Upon Him' (Hansen, 2006a: 9), which included the 12 cartoons and, it was reported, 'three additional cartoons of unknown origin: one shows Mohamed with a pig's snout, one shows the Prophet as a dangerous paedophile and the third shows a Muslim at prayer being buggered by a dog' (Lawson, 2006). It was later revealed that the image containing the pig's snout was in fact a contestant at a French, not Danish, pig-squealing contest and had nothing to do with insulting Islam (Hansen, 2006a: 9). The dossier also included 'pictures from another Danish newspaper, anti-Muslim hate mail, a televised interview with Dutch member of parliament Ms. Ayaan Hirsi Ali, who received the Freedom Prize from the Danish Liberal Party’ (Hansen, 2006a: 9), and is a regular critic of misogynistic uses of Islam. In February 2008, the cartoons were reprinted by several Danish newspapers, including Jyllands-Posten, in response to the arrest of three people accused of plotting to murder Kurt Westergaard, who penned the bomb/turban cartoon (Olsen, 2008).

The 12 cartoons are all very different and only the most rigid of readings could argue they are equally offensive, blasphemous, racist or Islamophobic. So, for example, one of the cartoons simply shows Muhammad with a stick, walking through a desert. This is perhaps the only one that does not contain an incongruity. Another is benign towards all versions of Islam that understand irony. As Hansen explains, 'One was a subtle attack on the paper itself: in it, Muhammed is not the Prophet but rather a young boy, a second generation migrant. He points to the chalkboard script: "The editorial team of Jyllands-Posten is a bunch of reactionary provocateurs" ' (Hansen, 2006a: 8). Similarly, one depicts Kåre Bluitgen in a turban, holding a stick figure of Muhammad, as an orange inscribed with 'publicity stunt' falls into the turban. As a report explained, "The proverb "an orange in the turban" is a Danish expression meaning "stroke of luck": here, the added publicity for the book' (Anon., 2006). Bleich (2006: 17) also comments on the diversity of the cartoons and states: 'it is not true that the cartoons universally contribute to Muslims' ethno-racial outsider status'. It is, therefore, fairly implausible to argue that three of the 12 cartoons are offensive or racist. They are, however, not all equally benign.

The humour theorist Arthur Asa Berger claims that 'it is much easier to ridicule someone, to make allusions about someone's transgressions and crimes, and to express contempt and loathing for someone visually by using caricature than it is in prose' (Berger, 1995: 144). The two cartoons generally considered most offensive draw on this potential. The first shows a sketch of Muhammad with a bomb in his turban. The second shows Muhammad with his eyes blacked out and holding a sword. Two women stand behind him wearing burkhas that only allow their eyes to be seen.

It is an important point, and one omitted from most commentaries, that a satirical cartoon is necessarily constructed with an incongruity or with a contrast, and that this incongruity encourages a number of ambiguous readings. In the first of the offensive 
cartoons, the image of Muhammad is juxtaposed with the image of a terrorist bomb and creates an incongruity because bombs are not worn in turbans. The second offensive cartoon plays on the prohibition of depicting Muhammad by showing him with his identity obscured. The mark of the censor on Muhammad's face becomes the focus of the incongruity, in contrast to the women behind him who have everything but their eyes obscured. This forms a visual opposition or incongruity that mocks both the prohibition of depicting Muhammad and the concept of women wearing burkhas. These incongruities lead to various reactions because they do not create a literal or denotative meaning. They set up chains of connotation and create the 'liquidity' of the images (for a commensurate account of the contextual ambiguity of visuals, see Müller et al., 2009).

Liquidity is an appropriate term for discursive meaning that is ambiguous. Zygmunt Bauman argues the " "Liquid modern" is a society in which the conditions under which its members act change faster than it takes the ways of acting to consolidate into habits and routines' (Bauman, 2005: 1). Such liquidity is characteristic of postmodernity, with its increase in the occurrence and experience of ambivalence.1 I propose that postmodern tendencies are exhibited in the structure and appearance of certain instances of racism, in what I call 'liquid racism'.

\section{Liquid Racism}

The existence of ambivalence and contradiction in the proximity of racist expression has been documented in the social sciences (e.g. Billig et al., 1988; Rattansi, 2007: 118, 120). This has led Rattansi to argue that there can be no essentialized racist subject (Rattansi, 2007: 118). Such research suggests that because subjects often negotiate contradictory discourses, some racist and some non-racist, a singular racist subjectivity is difficult to identify. I argue elsewhere that traditional forms of racist humour can act as rhetorical devices that resolve the ambiguities of racism and so aid the task of negotiation (Weaver, 2007). We see later that certain readings of the cartoons are involved in this process. By developing the concept of 'liquid racism', I would like to move the discussion of racism and ambivalence 'away' from the proximity of the subject, to show how certain cultural signs can contain the ability to produce simultaneous and ambiguous racist and non-racist readings.

Liquid racism is a racism generated by ambiguous cultural signs that encourages the development of entrenched socio-discursive positioning, alongside reactions to racism, when reading these signs. The images are ambiguous because they combine the signs of older racisms alongside those of political and social issues that are not necessarily racist. The development of entrenched positioning occurs because, and as is unpacked later, the ambiguity of the images create and encourage fundamentalist reactions. 2 Reactions to the images as racism occur as the reader connects primarily with the signs of older racisms.

The term 'liquid racism' gives the impression that we are now faced with a racism whose structure has changed and is obviously less solid than traditional racisms. The metaphor can be unpacked significantly. Bauman describes the 'liquid modern' as a society without solid patterns or routines, under processes of constant change that have accelerated. It is a society where the meaning of identities, objects and 'others' frequently shift position and mutate. Bauman does not discuss racism in detail in his corpus on liquid modernity and so I wish to develop the term 'liquid racism' to identify cultural signs that exhibit some of the tendencies of post/liquid modernity. Liquid racism is generated by interactions between the sophisticated rhetoric of 
racism in society, the complexity and diversity of ethnic identity and continuous population movements.

Liquid drastically loses its shape when it is removed from its 'container'. This suggests that liquid racism is one that needs a 'container' in which to be viewed, yet cannot produce a monolithic reading. Individual subjects may, therefore, develop particular semantic containers according to context and circumstance. Structurally, an increase in the 'volume' of sign-slippage in liquid racism allows for no straightforward way of establishing or asserting any semantic superiority of interpretation, making critique more challenging. Liquid racism has a malleable form that has far more potential for ambiguity, and this, we will see, paradoxically encourages and polarizes fixed readings. Rattansi (2007: 122) describes the 'polarised shouting matches from entrenched positions' that often appear in debates of racism. These are common around liquid racism. The content of liquid racism is constructed through the referents of cultural racism and embodied racism but the increased volume of its assemblage will create many potential readings, and this will affect its overall definitions of the 'other' which are multiple and protean.

The increased ambivalence of liquid racism means that it may be difficult to define, or that its definition may shift. This does not mean that such formations are not experienced by social actors as racism, as older forms of racism are. In many instances, because of its structural ambiguity, the impact may not be taken seriously because it is invisible from certain perspectives. This continues the development of immunity to criticism exhibited in the shift to postwar, postcolonial, cultural racism.

The concept of liquid racism presents two questions: is liquid racism really a new racism or just older racisms hiding themselves better? If liquid racism is genuinely more open then the argument surely suggests itself that it is not racism at all, or is a weakened and challenged residue of racism? To answer the first question, liquid racism uses both embodied and culturally racist signs but it is more ambiguous and contains more semantic layers. Further research will uncover the extent of liquid racism, both socially and historically, and so its newness is open to more complex readings. It certainly appears 'new' in terms of structure but decidedly old in terms of content. Bauman's thesis on liquid modernity suggests there are socio-semantic formations that proliferate in a global age, that are perhaps new in terms of the level of complexity of readings generated.

On the second question, liquid racism should not be seen as a specifically weakened or challenged residue of racism but rather as an ambiguous form that is specifically encouraged nowadays and one that weakens various defences against claims of racism. It is a form of racism that is promoted and encouraged by the mass media. It is ambiguous but, crucially, this ambiguity has, in part, encouraged media interest. In an age of interactive and polyvocal media, liquid racism generates a 'debate', providing more material and more positions to debate because it is ambiguous. Traditional monosemic racism fails to provide this potential and so is less media friendly or malleable and less open to exploitation for media content. Liquid racism also leads to the specific staging of proteophobic and proteophilic oppositions in media debate - all social actors need to do is take a side. It remains that many social actors do not 'read' liquid racism in its complexity, and so, as is explained later, it is as much reader interpretation and (lack of) reflexivity, as well as the expression of liquid racism, that is in need of critique. 


\section{Four Readings of the Cartoons}

In creating this liquidity, descriptions of the cartoons (which focus on the two deemed most offensive) give them several meanings, which can coexist because of the incongruity or ambiguity of the visual images. These can be summarized as:

1. The cartoons are a criticism of Islamic fundamentalism.

2. The cartoons are blasphemous because they depict Muhammad, so are insulting to Muslims and an attack on Islam.

3. The cartoons suggest Muhammad is a terrorist and thus imply that Muslims are terrorists by association. This stereotype is Islamophobic and racist.

4. The cartoons are satirical and should be defended under the principle of freedom of speech

Most reactions to the cartoons see one reading and develop it as the most valid, or regard one reading as the most offensive. Some take one reading as the most politically expedient and so construct a rhetorical argument for the realism of that reading and against its opponents (e.g. Hervik, 2008, in relation to reading 3). Such accounts do not read the cartoons as signs that exist in a specific semiotic 'frame' and most do not consider issues of polysemia in relation to any particular reading of the cartoons. Such readings inflict erasure on each other and encourage the liquidity of the controversy.

\section{A Criticism of Islamic Fundamentalism}

The first reading, a criticism of Islamic fundamentalism, is developed in the comments of Westergaard, the cartoonist of the bomb/turban cartoon, and by Rose. In explaining his 'stated' meaning, Westergaard argues:

The cartoon is not about Islam as a whole, but the part that apparently can inspire violence, terrorism, death and destruction. And thereby the fundamentalist part of Islam. I wanted to demonstrate that terrorists get their spiritual ammunition from Islam. There are interpretations of it that are incorrect. The general impression among Muslims is that it is about Islam as a whole. It is not. (Westergaard, 2006)

Westergaard insists that the bomb/turban cartoon should not be read as racist and Islamophobic. In line with this, but with a less specific focus, the 12 cartoons surround an article on self-censorship and freedom of speech. The comments of Flemming Rose illuminate the sentiment of the article and express a reading close to Westergaard's:

The modern, secular society is rejected by some Muslims. They demand a special position, insisting on special consideration of their own religious feelings. It is incompatible with contemporary democracy and freedom of speech, where you must be ready to put up with insults, mockery and ridicule. (Rose, 2005)

These statements are described as the 'stated' rather than the 'intended' meaning for two reasons. First, the cartoonists and Rose, in anticipation of the proceeding debate and protest, had an interest in presenting a particular form of intentionality that might disguise the thoughts or motives behind the piece. Put simply, any anti-Muslim or broadly racist motivation would be downplayed. Second, the individuals involved 
may not have been completely aware of their own intentionality when they created the cartoons. Freud's (1991 [1905]) theory of joking offers a number of insights that aid this discussion. Freud argued that humour results from a nervous release of energy, and that jokes often have a similar function to dreams or slips of the tongue because they represent the expression of repressed thoughts, or thoughts that are not socially acceptable as serious discourse. For Freud, tendentious jokes either express hostility, aggression or have a sexual content, which includes most jokes that generate insult. Freud considered there to be an element of self-denial in tendentious humour, that the joke involves an act of self-deception by the joker. This suggests intentionality is an ambiguous concept and one difficult to prove.

Much has been said on the conservative politics of Jyllands-Posten (Bleich, 2006; Carens, 2006; Hervik, 2008; Modood, 2006a, 2006b), and it seems obvious that the cartoons were intended to provoke a reaction from some Muslims at some level, as well as offending their religious sensibilities. While conservative journalists have equal rights of expression, of course, the comments of Rose do paint a stereotypical image of Muslims in Europe, although he is careful to only accuse 'some Muslims'. As a conservative newspaper, Jyllands-Posten may have seen the exercise as a worthwhile task, for the greater good as they see it.

I do not make an argument for censoring the cartoons or other instances of offensive satire. Censoring satire would likely prove self-defeating and encourage increasingly coded forms of racist expression, and where racism is debated or ambiguous, might lead to a subtle authoritarianism. Moreover, discussions of censure in the debates that followed seemed to miss the point of the initial article on selfcensorship (e.g. Modood, 2006a, 2006b). Most commentators also fail to mention that the structural ambiguity of satire complicates a comparison with hate speech (cf. Bleich, 2006). Humour, while not always funny, is a linguistic or visual frame that differs from serious communication. It is difficult to convincingly argue that it could be censored on the grounds of it being intended to generate specific serious reactions. Despite this, humour does support racism, and it is possible to outline the rhetorical potential of such images, and to argue that humour is often more than 'just humour'. The 'seriousness' of humour is such that its rhetorical effects are often more pointed because they are ambiguous and difficult to place inside categories such as hate speech. The stated meaning of the cartoons gives no basis on which to accuse anyone of hate speech, and while hate speech legislation often focuses on effect, on speech that might stir up hatred, the target is not usually the speaker. In the case of the cartoons controversy, those involved in their production received threats while there was a notable absence of any obvious cases of incitement of hatred or violence towards Muslims (Ammitzbøll and Vidino, 2007).

\section{Blasphemous Images}

The 'blasphemous reading', the idea that the cartoons are an insult to Islam, appears in both direct protest and commentary. In outlining it, Yasmin Alibhai-Brown offers a description of the outrage caused by the cartoons: 'Flemming Rose . . . sought out controversial cartoonists to create caricatures of the Prophet Mohamed, not because they had something bold and compelling to say, but simply to enrage, like bullfighters goading a bull' (Alibhai-Brown, 2006). Hansen explains how in October 2005, 'Muslim organisations in Denmark filed a complaint against the paper, claiming the publication constituted blasphemy under a rarely invoked section of the Danish criminal code' (Hansen, 2006a: 9). The blasphemous reading also gained purchase in Muslim countries where the dossier was publicized and unrest provoked. An example 
is reported by Katherine Butler: 'the sense of outrage at what is being depicted as an orchestrated Western assault on Muslim sensibilities, appears to cut across Pakistani society' (Butler, 2006). She adds 'Major General Shaukat Sultan Khan, the President's spokesman, said the "blasphemous sketches" could be "detrimental to world peace. . . . Moderate or non-practising Muslims are as one on this. It is like shoving pork down our throat" ' (Butler, 2006). These extracts highlight one reading of the cartoons, as they develop as a trope that holds both anti-western prejudice and offence at blasphemy.

There are different interpretations inside this reading. Some see the cartoons as a comment on the state of civilized society. These argue that because the cartoons show a lack of respect towards the faith of Muslims they are not reflective of ideal discourse in a civilized society. One letter to The Independent argues that, 'Respect for other faiths is the basis of civilised society, particularly when we are living in an increasingly multi-faith and multi-cultural world where peace and harmony can only be achieved through understanding the sensitivities of others' (Malik, 2006).3 On the other hand, some examples of the reading express threats. For example, Robert Fisk reports how:

The Islamic Army in Iraq, one of the main insurgent groups, made a blood-curdling call yesterday for violence against citizens of countries where caricatures of the Prophet Mohammed had been published. 'We swear to God, if we catch one of their citizens in Iraq, we will cut him to pieces, to take revenge for Prophet,' it said in an unverified internet statement [sic]. (Fisk, 2006)

While the Islamic Army in Iraq is not necessarily a fundamentalist organization, it is a violent one, and this reaction to the cartoons, and other threats of violence, represent a response that echoes the stated meaning. Most commentators suggest that it would be a retrograde and authoritarian act to reinstate blasphemy as a serious offence. As such, other grounds of complaint are called upon to render criticism of the cartoons, or to reformulate the charge of blasphemy.

\section{Islamophobia and Racism}

The dominant sociological critique of the cartoons argues that they are culturally racist and an example of Islamophobia. The culturally racist reading is not one that is widely articulated in the media; in fact, it is an important point that most protests against the cartoons do not say that the cartoons are racist. This idea emerges in academia and is dependent on the concept of Islamophobia. An initial incoherence in this argument is that it forms an example of sociological mistranslation: the application of ill-fitting sociological categories to discourse that expresses outrage with quite different terms and concepts. So, for example, Hansen, in a survey of 113 newspaper articles, found that 'Of those who took a position, 58 (43\%) argued that the cartoons were offensive to Islam, while seven (5\%) said they were both offensive to Islam and racist' (Hansen, 2006b: 49). Racism does not appear from the outset to be the major cause of complaint. This does not discount that the cartoons may be motivated by, and create, anti-Muslim racism but it does suggest that anti-racism may not be the only motive for reaction - thus highlighting the liquidity of the cartoons.

Islamophobia sees the religion of the Muslim as 'other'. As Modood (2005a: 11) outlines, 'religion can be the basis of racialisation as long as the religion of a group can be linked to physical ancestry and descent'. Incompatibility with European culture is also regularly cited as a characteristic of Islam by Islamophobes (Balibar, 
1991: 24). Anti-Muslim and anti-Asian racism exists and should be taken seriously and this also involves a rigorous approach to the concepts used in identifying it. 'Islamophobia' is a contested term and one critiqued as too broad (Halliday, 1999). Importantly, to describe cultural racism as new or more sophisticated is to describe it as increasingly polysemic. Islamophobia is a racism that often exhibits the coding, ambiguity or polysemia common in cultural racism. As Rattansi (2007: 111) states ‘ "Islamophobia" or any other kind of hostility to Islam and Muslims is not necessarily racist, but in many contexts can take a relatively "strong” or "hard” racist form.' This is further complicated when combined with the ambiguity of the cartoons.

The idea that the cartoons stereotype Muslims or are Islamophobic appears in some press comment. One in The Independent expresses this: 'As there is no suggestion in history that he was a terrorist, the figure is clearly a proxy for all Muslims' (Shamsad, 2006). Another argues:

To imply that his teachings legitimate terrorist activities is in itself a deliberate act of incitement to hatred. The purpose behind the publication and re-publication of the cartoons was deliberate provocation, based on a belief that Muslims are fair targets for any kind of insults. (Hasan, 2006)

The idea that the cartoons represent a deliberate act of provocation, that they are clearly a proxy for all Muslims, that this is the intended and only meaning, is impossible to sustain. It is clearly one reading, but not the only one, and so highlights the liquid aspect of the debate. Importantly, the cartoons allow, because of their incongruity, for Islamophobia to be implied in readings of them. Paradoxically, this implication fails to allow for clear or serious racist intent to be proven.

Sociological accounts have developed the racist reading. Modood suggests:

... the cartoons are not just about one individual but about Muslims per se - just as a cartoon portraying Moses as a crooked financier would not be about one man but a comment on Jews. And just as the latter would be racist, so are the cartoons in question. (Modood, 2006a: 1)

Analogies between the Prophet Muhammad cartoons and various examples of antiSemitism or anti-Semitic cartoons highlight that religious groups can be racialized. Modood's example makes clear that to see Islam and terrorism as inherently connected is a cultural stereotype and thus culturally racist but it does not prove that the 'Muslim terrorist' is socially and historically entrenched in the same way as the 'rich crooked Jew'. The analogy rhetorically draws on anti-Semitism for support and invokes the image of pre-Second World War anti-Semitic stereotyping. Perhaps the most problematic aspect of this comparison is the implicit assertion that western European anti-Muslim racism has, in recent history, impacted on Muslims in the same way that anti-Semitism impacted on Jews. Moreover, the analogy also erases the reality of European Islamic fundamentalism, which is often seen as a legitimate target for satire.

That said, an anti-Muslim racist reading of the cartoons has been developed by the British National Party, who use it for supporting culturally racist ideology. In this case the cartoons are used as a signifier of all Muslims and are situated as a way of expressing proteophobia. Robert Verkaik reports that, 'The British National Party has published some of the cartoons on its website. "British newspapers have united in their cowardice by refusing to carry the cartoons which have caused a storm of protest 
and anger amongst the Muslim world”, read the accompanying statement' (Verkaik, 2006). The BNP was reported to have used one of the cartoons in the May 2006 local authority elections, as Andrew Grice writes that the BNP 'will include in its campaign material one of the cartoons which sparked outrage among Muslims across the world, showing the Prophet Mohamed with a bomb in his turban' (Grice, 2006). Such uses confirm the ambiguity of the images and the necessary rigidity of the reader who can 'overcome' this. The power of the cartoons lies in the distortions created. The cartoons generate a form of liquid racism that requires the addition, consumption and subsequent negation of the other readings in order to sustain its persuasiveness.

\section{Satire and the Defence of Free Speech}

In defining satire, Stott (2005: 109) states that it 'aims to denounce folly and vice and urge ethical and political reform through the subjection of ideas to humorous analysis'. This presents the idea that humour is able to analyse serious events in a particular way. As stated, it might represent the partisan ridicule of a political position and a rhetorical expression of ideology, as ethics are rarely objective. It also points to the specific semantic alienation of the object of humour - through the creation of a separation between self-definition and definition through ridicule. Griffin (1994: 37) adds a similar comment: 'satire works like the preacher-rhetorician to persuade his audience to virtue'. I have explained that the specific targets of the cartoons are ambiguous. Contrary to this, for example, Sardar (2006: 1) argues: 'A cartoon is a satiric device. Satire holds a mirror to the powerful, speaking truth to power. But European Muslims can hardly be described as powerful.' This firmly sees the cartoons through the culturally racist lens, but if one takes the target to be Islamic fundamentalism, then they do have a satirical and ethical reading. It seems, then, that the targets of the cartoons are multiple, and thus, so are the ethical impacts.

It is hardly a new phenomenon for satire to be offensive to its target and cause outrage. For example, Stott (2005: 106) explains that in Aristophanes' comedy: 'Abuse that we would now consider libellous was a fundamental part of comedy.' Following the trend of offensiveness, Greek satire became influential in the 18th century as 'English authors rediscovered satirical models as a powerful form of social commentary' (Stott, 2005: 112). Many of the examples in Gatrell's (2006) City of Laughter show the insulting nature of London's 18th-century satire. It is the stretching of incongruity in satire that encourages the ridiculous meaning. Hence, satire is never nice, gentlemanly or civil, and has frequently encouraged the authoritarian response of reaching for the censor's mark.

Returning to the Prophet Muhammad cartoons, on the satirical side of the coin (or incongruity) is the liberal secular reading and defence of freedom of speech, which is also a defence of satire. The stated meaning of the cartoons, summarized as a comment on Islamic fundamentalism and a defence of freedom of speech in reaction to self-censorship, was, in the proceeding debates, championed by a number of writers and journalists. Some of these do acknowledge that the cartoons may be genuinely offensive to Muslims, but very few touch on the issue of racism in any depth. Johann Hari exemplifies this position:

Surely the only position for a liberal and a democrat to take is to rally to the side of the cartoonists? . . . free speech is not freedom to be nice. It is freedom to be offensive, foolish or even racist, or it is nothing. (Hari, 2006a)

As his argument develops, the defence becomes more determined: 
A poisonous cliché sprang up: that this is a fight between 'Liberal fundamentalists' and Islamic fundamentalists, two equally extreme sides that reasonable people should reject. Do these people really believe there is a moral equivalence between a system of free speech that protects everyone, Muslims included, and a superstitious taboo that proposes to erect a wall around one man and silence all criticism of him? (Hari, 2006a)

The liberal secular reading develops from the stated meaning. By denying concern for the interpretation of the cartoons, it becomes a defence of principle that attempts to position itself externally to the meanings that are created by the cartoons. The second quote emphasizes this, as Hari begins to give normative judgement on the wider arguments. Later he comments on the London demonstration against the cartoons:

This year, London has seen more than one mass rally in favour of censorship. The enemies of free speech recur throughout the ages, appalled by Michelangelo, Galileo, DH Lawrence . . . and today, it is cartoon depictions of Mohamed that stoke their rage. Tomorrow it will be something else, perhaps something you love. (Hari, 2006b)

This view is supported in many commentaries: for example, Greg Dyke offers a viewpoint on why the British press had not reproduced the cartoons, through recounting comments made by Salman Rushdie:

He told us that our tolerant liberal society which we had fought to establish over centuries, was in danger of being destroyed from within because that very tolerance meant we tolerated people who didn't share those same values and, as a result, they would undermine them. I have a horrible feeling that this is what is happening today. (Dyke, 2006)

These debates assert the defence of a principle - freedom of speech. Being directly caught up in the unfolding discourse and characteristic of journalistic commentary, where opinion is paramount, there is little attempt to say anything about the way in which the debates have developed as a direct result of the semantic structure of the cartoons, thus they perpetuate the liquid aspects of the debate. Certainly the debates capture important points but many become as entrenched as the other positions do. In doing so they tend to forgo discussions of categories of 'free' and 'hate' speech, in relation to racism and the cartoons, that might highlight unacknowledged contradictions in their discursive positioning.

\section{Postmodernity and Fundamentalism}

There is . . . a specifically postmodern form of religion, born of the internal contradiction of postmodern life, of the specifically postmodern form in which the sufficiency of man and the banality of dreams to take human fate under human control are revealed. This form has come to be known under the English name of fundamentalism. (Bauman, 1997: 182; emphasis in the original)

There is a postmodern tendency at work in the cartoons controversy. Readings of the cartoons become fixed when the position of the reader becomes entrenched, or at a more extreme level, fundamentalist. This was evident in the BNP's use of the 
cartoons and in the violent reactions towards non-Muslim Europeans from some Muslims.

While the BNP's use of the cartoons encourages racism, there was also an ostensive display of anti-European hatred expressed in the violent protest surrounding the cartoons. For example, Hansen (2006a: 9) states that 'On 30 January, armed gunmen in the Gaza strip stormed the European Union office in Gaza, threatening to kidnap the workers unless the EU issued an official apology. Hamas's leaders demanded that Denmark punish the cartoonists and Jyllands-Posten.' Further to this, in Europe there were also expressions of violent intent:

Demonstrations were organised outside the Danish embassy in London, during which radical Islamists brandished placards stating: 'Slay [also butcher/massacre/behead/ exterminate] those who insult Islam', 'Free speech go to hell', 'Europe is the cancer and Islam is the cure', and 'Europe will pay, your 9/11 is on its way'. (Hansen, 2006a: 10)

An organizer at the London protest, Umran Javed, was later found guilty of inciting racial hatred. Shenai Raif reports that 'He was said to have shouted: "Bomb, Bomb Denmark, Bomb, bomb, USA" ' (Raif, 2007). What is significant is that the vitriol generated in these reactions is in response to a series of ambiguous cartoons. This is a fundamentalist reaction to liquid racism.

Bauman argues that fundamentalism, both religious and non-religious, is a tendency that is a specific product of postmodernity. He suggests,

. . . fundamentalism is the supreme (though radically simplified) embodiment of a tendency aided and abetted by the whole thrust of postmodern culture. One may conclude that religious fundamentalism is a legitimate child of postmodernity, born of its joys and torments, and heir to its achievements and worries alike. (Bauman, 1997: 184)

Bauman sees postmodernity as a period in which there is a notable and significant increase in the occurrence and experience of ambivalence, instability, liquidity and the predictable anxiety that results from this. The postmodern condition is also said to lead to an increase in individualism, both chosen and prescribed. Bauman argues that “ "Fundamentalism", choosing to hold fast to inherited and/or ascribed identity, is a natural and legitimate offspring of planet-wide enforced individualisation' (Bauman, 2005: 27). Fundamentalism is, therefore, a reaction to an ambivalent world and an attempted reordering of that world through its reinscription.4 Following this rationale, fundamentalism has, for Bauman, an equivalent relationship to ambivalence as fascism. Hence, he argues that 'religious fundamentalism belongs to a wider family of totalitarian or proto-totalitarian solutions offered to all those who find the burden of individual freedom excessive and unbearable', that it 'is an offer of an alternative rationality' (Bauman, 1997: 184, 185; emphasis in the original). The cartoons, when viewed through a fundamentalist lens, become the ambiguous, non-literal antithesis of that identity. The ambivalence feeds fundamentalism as the very thing that it cannot stand and wishes to remove from the world. This reverses the pattern found around traditional racist humour, where rather than it being a discourse of hatred of the 'other' that forms the impetus for joke creation, hatred is expressed as outrage towards the created incongruity (Weaver, 2007).

The Prophet Muhammad cartoons have an ambiguous and liquid form. It is the incongruity, in addition to the complexity of the political debates, that construct the 
nucleus of this liquidity. They are, therefore, an article of culture that one might, quite fairly, be ambivalent about, especially when we are discussing the serious arguments of what they are really intended to mean, and what should be done with them. This article demonstrates that further discussion and investigation of polysemia, ambivalence and racism, especially cultural racism, now seems necessary and urgent.

\section{Conclusion}

The article has highlighted the development of liquid racism - a racism of ambiguous cultural signs that encourages the development of entrenched socio-discursive positioning when reading these signs. Examples of entrenched positioning have been drawn from four perspectives that encompass the stated meaning, complaints of blasphemy, complaints of racism and a defence of satire and freedom of speech. The concept of liquid racism should allow us to identify racism where the sign-systems that make it up are entwined with not just the ambivalence of racist subjectivity but also an assemblage of issues, perspectives and contexts of reading. It is certainly important for the sociology of race and ethnicity to gauge this complexity and to hope to do more than (re)produce shouting matches with inflexible concepts. Further research may also highlight other examples of liquid racism alongside the continued existence of older formations.

The Prophet Muhammad cartoons are an ambiguous form and there is no one true or correct reading of them. This structural ambiguity does not preclude them from producing racist readings. They also have the ability to provoke fascist or fundamentalist responses. Such complexity shows that liquid racism does not signify an unimportant racism or a racism less serious than traditional forms. It is serious because it signifies the paradox that a war of words over what they mean and whether they should be condemned will ignite rather than defuse the volatility of ambiguous images.

\section{Notes}

I wish to thank the three anonymous reviewers for their helpful comments on the article. Thanks also to Michael Pickering for his useful comments, and to Gregor McLennan and Thomas Osborne for guidance on an earlier version. The article was finalised during an ESRC funded Postdoctoral Fellowship (PTA-026-27-2168).

1. Overall, there is no substantive difference between Bauman's definitions of postmodernity and liquid modernity - apart from the metaphorical potential of the term 'liquid' - which is unquestionably his dominant argumentative technique. I maintain a use of postmodernity but draw on the metaphor of liquidity in describing certain socio-discursive formations.

2. Fundamentalism (Islamic and other forms) is defined as an appeal 'to the inerrancy of sacred texts to legitimate conceptions of purity' (Springett, 2003: 325). It is also a fixation on 'society's desertion of eternally valid, divinely revealed and textually literal received principles of order' (Riesbrodt, 1993: 16, cited in Springett, 2003: 328-9). Such cultural discursive interpretations are not always linked to violent activity.

3. Letters to the editors of daily newspapers have been included in the analysis because, while differing greatly from reportage, press commentary and academic publications on a number of levels, they provide excellent examples of the liquid readings of the 
cartoons. They often very clearly express the polarity or specificity of the forms of reaction provoked by liquid racism.

4. See also Springett (2003) for a commensurate psychoanalytic account of anxiety, ambivalence and the resulting discursive fixity in all religious fundamentalisms, and sociological accounts of the reordering, reactive and monosemic characteristics of Islamic fundamentalism (Alam, 2007: 32; Brighton, 2007: 13).

\section{References}

Alam, A. (2007) 'Political Management of Islamic Fundamentalism: A View from India', Ethnicities 7(1): 30-60.

Alibhai-Brown, Y. (2006) 'The Double Standards over Free Speech', The Independent 6 February: 14.

Ammitzbøll, P. and Vidino, L. (2007) 'After the Danish Cartoon Controversy', Middle East Quarterly Winter: 3-11; at: www.meforum. org/article/1437 (accessed 10 March 2008).

Anon. (2006) 'Jyllands-Posten Muhammad Cartoons Controversy'; at: en.wikipedia.org/ (accessed 24 April 2006). Original Danish text from the JyllandsPosten website; at: www.jp.dk/indland/artikel:aid=3579530/

Balibar, E. (1991) “'Is There a “Neo-Racism”?’, in E. Balibar and I. Wallerstein (eds) Race, Nation, Class: Ambiguous Identities, pp. 17-28. London and New York: Verso.

Bauman, Z. (1997) Postmodernity and its Discontents. Cambridge: Polity.

Bauman, Z. (2005) Liquid Life. Cambridge: Polity.

Berger, A. A. (1995) Blind Men and Elephants: Perspectives on Humor. New Brunswick, NJ and London: Transaction Publications.

Billig, M., Condor, S., Edwards, D. and Gane, M. (1988) Ideological Dilemmas: A Social Psychology of Everyday Thinking. London, Newbury Park, CA and New Delhi: Sage.

Bleich, E. (2006) 'On Democratic Integration and Free Speech: Responses to Tariq Modood and Randell Hansen’, International Migration 44(5): 17-22.

Brighton, S. (2007) 'British Muslims, Multiculturalism and UK Foreign Policy: “Integration” and “Cohesion” in and beyond the State', International Affairs 83(1): $1-17$.

Butler, K. (2006) 'Two Die in Cartoon Protests as Pakistani Violence Worsens', The Independent 15 February; at: www.independent.co.uk/news/world/asia/two-die-incartoons-protest-as-pakistani-violence-worsens-466633.html (accessed 10 April 2006).

Carens, J. H. (2006) 'Free Speech and Democratic Norms in the Danish Cartoons Controversy', International Migration 44(5): 33-42.

Dyke, G. (2006) 'Why Did the Media Choose not to Show the Cartoons of Mohamed?', The Independent (Media Weekly) 13 February: 13.

Fisk, R. (2006) 'The Fury', The Independent 6 February: 1.

Freud, S. (1991) Jokes and their Relation to the Unconscious, ed. A. Richards, trans. J. Strachey. London: Penguin. (Orig. pub. 1905)

Gatrell, V. (2006) City of Laughter. London: Atlantic Books.

Grice, A. (2006) 'BNP to Use Prophet Cartoons in Campaign', The Independent 22 February: 12.

Griffin, D. (1994) Satire: A Critical Reintroducton. Lexington, KY: The University Press of Kentucky.

Halliday, (1999) “ “Islamophobia” Reconsidered', Ethnic and Racial Studies 22(5): 892-902. 
Hansen, R. (2006a) 'The Danish Cartoon Controversy: A Defence of Liberal Freedom', International Migration 44(5): 7-16.

Hansen, R. (2006b) 'Free Speech, Liberalism, and Integration: A Reply to Bleich and Carens', International Migration 44(5): 42-51.

Hari, J. (2006a) 'Free Speech for All, Abu Hamza Included', The Independent 9 February: 12.

Hari, J. (2006b) 'Defend Free Speech for Everyone', The Independent 22 March: 12.

Hasan, K. (2006) 'Cartoons Are Part of a Campaign of Hatred', The Independent (Letters to the Editor) 9 February: 34.

Hervik, P. (2008) 'The Predictable Responses to the Danish Cartoons', Global Media and Communication 2: 225-30.

Lawson, D. (2006) 'Hysteria, Hypocrisy and Half-Truths', The Independent 7 February: 27.

Malik, N. (2006) 'Freedom of Speech, But with Respect', The Independent (Letters to the Editor) 24 February: 32.

Modood, T. (2006a) 'The Liberal Dilemma: Integration or Vilification?', Open Democracy 8 February; at: www.opendemocracy.net/faithterrorism/liberal_dilemma_3249. jsp (accessed 10 April 2006).

Modood, T. (2006b) 'The Liberal Dilemma: Integration or Vilification?', International Migration 44(5): 4-7.

Müller, M. G., Özcan, E. and Seizov, O. (2009) 'Dangerous Depictions: A Visual Case Study of Contemporary Cartoon Controversies', Popular Communication 7(1): 2839.

Olsen, J. M. (2008) 'Papers Republish Mohamed Cartoons', The Independent 14 February; at: www.independent.co.uk/news/europe/papers-republish-mohamedcartoon-782028.html (accessed 12 March 2008).

Raif, S. (2007) 'Man Guilty of Inciting Race Hate at Danish Cartoon Protest', The Independent 6 January: 12.

Rattansi, A. (2007) Racism: A Very Short Introduction. Oxford: Oxford University Press.

Rose, F. (2005) 'Jyllands-Posten: Ytringsfrihed: Mohammes anisgt', translation from 'Jyllands-Posten Muhammad Cartoons Controversy'; at: en.wikipedia.org/ (accessed 24 April 2006).

Sardar, Z. (2006) 'A "Freedom” Whose Home is the Jungle: This is an Issue of Power, Domination and Demonisation', The Independent on Sunday 5 February: www.independent.co.uk/opinion/commentators/ziauddin-sardar-a-freedom-whosehome-is-the-jungle-465592.html (accessed 10 April 2006).

Shamsad, R. (2006) 'Cartoons Attack Me and My Family', The Independent (Letters to the Editor) 8 February: 28.

Springett, J. (2003) 'Religious Fundamentalism and Primitive Projective Processes', Psychoanalytic Psychology 17(4): 325-41.

Stott, A. (2005) Comedy. New York and London: Routledge.

Verkaik, R. (2006) 'Muslims Rally Organisers Tell Extremists to Stay Away', The Independent 11 February: 10.

Weaver, S. (2007) 'Humour, Rhetoric and Racism: A Sociological Critique of Racist Humour', unpublished PhD thesis, University of Bristol.

Westergaard, K. (2006) 'Jyllands-Posten Muhammad Cartoons Controversy'; at: en.wikipedia.org/ (accessed 24 April 2006). Original Danish text from the JyllandsPosten website; at: www.jp.dk/indland/artikel:aid=3579530/ 
Whittam Smith, A. (2006) 'Of Course Press Freedom Matters, but the Sacred in All Religions Deserves Respect', The Independent 6 February: 29.

Biographical Note: Simon Weaver is a visiting research fellow in the Department of Social Science at Loughborough University. Prior to this he was an ESRC postdoctoral fellow in the same department. Simon's research interests focus on three areas. First, cultural, social and communication theory, particularly the work of Zygmunt Bauman and the field of semiotics. Second, humour and rhetoric, especially in relation to racist and other forms of offensive humour. This is extended to an interest in the relationship between humour, offensiveness and issues of free speech and censorship. Third, 'race' and ethnicity in media, culture and society.

Address: Department of Social Science, Loughborough University, Loughborough LE11 3TU, UK. [email: S.Weaver@lboro.ac.uk] 